\title{
Caravelas à Vista: Giros Decoloniais e Caminhos de Resistência na Formação de Professoras e Professores que Ensinam Matemática $^{1}$
}

\section{Caravels in Sight: Decolonial Turns and Paths of Resistance in the Education of Teachers who Teach Mathematics}

\author{
Victor Giraldo ${ }^{2}$ \\ Filipe Santos Fernandes ${ }^{3}$
}

\section{RESUMO}

Este ensaio assume uma opção decolonial para debater a formação de professoras e professores que ensinam matemática. Articulando onze estudos aceitos no GT19 - Educação Matemática, da Associação Nacional de Pesquisa e Pós-Graduação em Educação (ANPEd), na ocasião de sua da 39ª Reunião Nacional, foi possível discutir traços e efeitos de colonialidade que se manifestam na formação de professoras e professores que ensinam matemática, apontando relações de poder, regulações e movimentos de resistência envolvidos nos espaços e tempos que compõem diferentes processos formativos. Para apresentar essa discussão, propomos três eixos que, em nossa interpretação pautada na decolonialidade, atravessam essas relações, possibilitando a construção de caminhos de resistência: coletivos docentes como espaços de resistência; metodologias em diálogos com saberes; e matemática como desobediência político-epistêmica. Esperamos que este ensaio nos desafie a assumir posições ativas, evidenciando papéis que a escola e a universidade têm exercido como instrumentos de um projeto de poder hegemônico de padrões coloniais; mas que também contribua para a construção de posicionamentos, posturas e horizontes de resistência, de transgressão, de intervenção e de insurgência no contexto da formação de professoras e professores que ensinam matemática.

PALAVRAS-CHAVE: Colonialidade. Decolonialidade. Educação Matemática. Formação de Professores que Ensinam Matemática.

\footnotetext{
${ }^{1}$ Trabalho encomendado para a 39a Reunião da Associação Nacional de Pesquisa e Pós-Graduação em Educação (ANPEd), GT19 - Educação Matemática, com o tema: Formação de professores que ensinam matemática em contextos de regulação e perdas de direitos: possibilidades e formas de resistência.

${ }^{2}$ Programa de Pós-Graduação em Ensino de Matemática e Programa de Pós-Graduação em Educação Universidade Federal do Rio de Janeiro. victor.giraldo@ufrj.br

${ }^{3}$ Programa de Pós-Graduação em Educação: Conhecimento e Inclusão Social - Universidade Federal de Minas Gerais. fernandes.fjf@gmail.com
} 


\begin{abstract}
This essay takes a decolonial stance to debate the education of teachers who teach mathematics. Articulating eleven studies accepted in the WG19 - Mathematics Education, of the National Association for Research and Graduate Studies in Education (ANPEd), on the occasion of its $39^{\text {th }}$ National Meeting, it was possible to discuss traces and effects of coloniality manifested in the education of teachers who teach mathematics, pointing out relations of power, regulations and movements of resistance involved in the spaces and times that constitute different educational processes. To present this discussion, we propose three axes that, in our interpretation based on decoloniality, pervade these relations, enabling the construction of paths of resistance: collectivities of teachers as spaces of resistance; methodologies in dialogue with knowledge; and mathematics as political-epistemic disobedience. We expect this essay to challenge us to take active positions, highlighting roles that school and university have been playing as instruments of a hegemonic project of power with colonial patterns; but also to contribute to the construction of positions, stances and horizons of resistance, transgression, intervention and insurgency in the context of the education of teachers who teach mathematics.
\end{abstract}

KEYWORDS: Coloniality. Decoloniality. Mathematics Education. Education of Teachers who Teach Mathematics.

\title{
Quem é a primeira pessoa desta narrativa?
}

Brasil, meu nego

Deixa eu te contar

A história que a história não conta

$\mathrm{O}$ avesso do mesmo lugar

Na luta é que a gente se encontra

Brasil, meu dengo

A Mangueira chegou

Com versos que o livro apagou

Desde 1500

Tem mais invasão do que descobrimento

Samba enredo História Para Ninar Gente Grande G.R.E.S. Estação Primeira de Mangueira - Carnaval 2019 Composição: Deivid Domênico, Tomaz Miranda, Mama, Marcio Bola, Ronie Oliveira e Danilo Firmino.

Na narrativa hegemônica sobre a história do Brasil, o suposto brado Terra à vista! tem sido frequentemente usado como uma referência - e uma idealização - do início do processo que essa mesma narrativa nomeia como "descobrimento do Brasil". Nessa versão da história, narrada do ponto de vista dos colonizadores, o brado Terra à vista! simboliza o primeiro vislumbre pelo homem branco, civilizado e europeu de uma terra selvagem, atrasada, desprovida de sabedorias, de almas ou de culturas. Sua heroica missão era, portanto, descobrir, desbravar, levar a luz e a civilização a essas terras virgens; tirar das trevas e do atraso esses pobres bárbaros. Para que se cumprisse essa missão heroica, seriam inevitáveis e justificáveis todos os sacrifícios e todas as violências - a escravização e o genocídio dos povos, o 
apagamento de sabedorias tradicionais, o assolamento das terras, o rasgar de fronteiras arbitrárias sobre o novo mundo.

Como observa Lander (2001), os pensamentos hegemônicos sobre e da América Latina, impostos desde então, podem ser caracterizados como essencialmente coloniais e eurocêntricos. Entretanto, a partir de movimentos de insurgência epistêmica, de resistência cultural, de lutas políticas e de mobilizações populares, também têm se produzido outras vertentes de pensamento, opções de conhecimento que buscam defender e preservar sabedorias ancestrais e produzir alternativas contemporâneas às racionalidades euro-eua-cêntricas. Autoras e autores latino-americanos nos campos das ciências sociais e humanas têm contribuído com essas vertentes.

Essas autoras e autores (e.g. MALDONADO-TORRES, 2007) têm denunciado a colonialidade como um padrão de poder que emerge como resultado do colonialismo territorial e político moderno - mas que sobrevive a este, não se limitando à dominação formal de um povo sobre outro, e operando nas formas como o trabalho, o conhecimento, a autoridade e as relações intersubjetivas se manifestam e se articulam entre si. Para o projeto de manutenção de dominação econômica e simbólica, a colonialidade promove a naturalização e a legitimação de dicotomias e de hierarquias culturais, sociais, políticas, territoriais, raciais, de gênero e sexualidade. Walsh (2008) destaca pelo menos quatro eixos interconectados por meio dos quais a colonialidade opera - colonialidade do poder, colonialidade do saber, colonialidade do ser, colonialidade da vida e da natureza.

A colonialidade se sustenta ainda em um mito da modernidade eurocêntrica que, segundo Dussel (1992), se caracteriza, dentre outros aspectos, pelo auto entendimento da civilização moderna como mais desenvolvida e superior e que, sendo assim, está moralmente autorizada e obrigada a impor processos civilizatórios aos povos inferiores, primitivos e bárbaros - independente da própria vontade dos povos e das violências produzidas nesses processos. Assim, como observa Lander (2001), por um lado, se produz uma concepção linear e unidirecional da história, que evolui de um estado mais atrasado (em geral, associado a uma visão mítica da natureza bruta) a um estado mais avançado (representado pela idealização da sociedade europeia); e, por outro lado, são invisibilizadas todas as outras histórias que coexistiam empiricamente antes da colonização do continente americano. Por meio desses processos, o mito da modernidade eurocêntrica se produz junto à naturalização das epistemologias hegemônicas, que são impostas como opções únicas. Em nome de uma noção 
de progresso linear, tudo que se alinha a essas epistemologias únicas é alçado a um lugar do avanço ou do desenvolvimento; ao passo que as sabedorias outras são relegadas a um lugar do primitivismo ou do atraso, sendo os próprios sujeitos culpabilizados por sua suposta condição.

Não obstante, como propõe Walsh (2017), junto à colonialidade emerge a decolonialidade, uma forma de (re)existir, de sustentar e (re)construir caminhos de luta permanentes em que se possam identificar e visibilizar sabedorias outras, e atuar a partir dessa identificação e visibilização. A decolonialidade se refere, portanto, a posicionamentos, posturas, horizontes e projetos de resistência, de transgressão, de intervenção e de insurgência. O uso do termo decolonialidade - ao invés de descolonialidade - marca uma opção epistemológica e política, cuja intenção é evidenciar que não há um estado nulo de colonialidade - como se fosse possível passar de um momento colonial a outro não colonial, sem a influência de seus padrões. A decolonialidade não nos impele, portanto, eliminar a colonialidade; mas nos desafia a desnaturalizar as epistemologias hegemônicas, a desaprender a pensar unicamente a partir de suas referências, e a retirar as sabedorias outras do apagamento, deslocá-las do lugar do atraso. Somos desafiados então a atuar em seus arredores, em suas fissuras, em suas rachaduras, como lugares de produção de possibilidades "do intercultural e do decolonial, não como substantivos fixos, mas como 'verbalidades' que despertam o seu agir ativo, a sua ação" (WALSH, 2017, p. 44, tradução nossa).

Dessa perspectiva, propomos neste ensaio assumir um giro epistêmico, materializado por uma inversão nos protagonismos de narrativas hegemônicas - em lugar de Terra à vista!, bradamos Caravelas à vista!. Assim, nos desafiamos a desaprender as versões da história do olhar único do colonizador que vislumbra a terra bruta a ser civilizada, para passar a narrá-la do ponto de vista dos povos e dos grupos colonizados e subalternizados - é deles a primeira pessoa desta narrativa.

Tal mudança na pessoa que narra não corresponde meramente a outra versão da mesma história, em que os povos colonizados contemplam passivamente a aproximação das caravelas carregando os dispositivos civilizatórios que apagarão suas culturas. A narrativa que propomos é uma subversão da história, na qual, em um movimento decolonial, esses povos tomam consciência da chegada das caravelas, apropriando-se delas, desmontando-as, subvertendo o uso de suas peças e usando-as em caminhos de resistência e de insurgência que produzem possibilidades de fortalecimento de poderes, valorização de saberes, afirmação de seres, de corpos e de formas de viver e de estar no mundo. Esta não é uma versão da história dos heróis 
e dos fatos heroicos que atuaram na invenção daquilo que hoje se chama Brasil, daquilo que hoje se chama Matemática ou daquilo que hoje se chama Formação de Professores; mas uma narrativa de grupos, de sujeitos e de sabedorias que foram e que são invisibilizados nesses processos.

Dialogar com as contribuições de outros colegas a partir de uma perspectiva decolonial é nossa intenção neste ensaio, embora haja outros caminhos possíveis para discutir as relações de poder, as regulações e os movimentos de resistência envolvidos nos espaços e tempos de formação de professoras e professores que ensinam matemática. Consideramos que a opção pela decolonialidade, em diálogo com a literatura de pesquisa em formação de professoras e professores nos campos da Educação e da Educação Matemática, tem a potência de deslocar esse debate para terrenos políticos situados nos diversos contextos latino-americanos, particularmente nos brasileiros, evidenciando especificidades desses contextos, das perspectivas dos sujeitos, das práticas e do projeto político-ético-estético.

Como destaca Maldonado-Torres (2007), a colonialidade não se limita a relações formais de dominação política, se espraiando nas formas de trabalho, de conhecimento, de autoridade, e nas relações intersubjetivas. Podem-se, portanto, evidenciar traços e efeitos de colonialidade nos contextos de formação e de práticas de professoras e professores, no que diz respeito tanto a grupos sociais subalternizados ou historicamente excluídos, como a relações entre professoras e professores e seus estudantes, entre professoras e professores em formação e formadores de professores, entre sujeitos e conhecimentos institucionalizados. Assim, no pensar com saberes e práticas mobilizados em espaços e tempos de formação de professoras e professores que ensinam matemática, a opção decolonial pode provocar interpelações políticas sobre de quem, para quem e em que estão referenciados esses saberes e práticas, na delimitação política, geográfica e cultural que hoje se denomina Brasil, e na delimitação política e epistemológica que hoje se denomina Matemática.

Procuramos identificar o que as autoras e os autores que contribuíram com este trabalho denunciam sobre relações de colonialidade na formação de professoras e professores que ensinam matemática, e o que propõem como caminhos de resistência, bem como revelar outras possibilidades de resistência a partir desse diálogo. A leitura dos onze estudos que compõem este dossiê nos permitiu identificar três eixos que, em nossa interpretação sob a opção da decolonialidade, atravessam suas contribuições e podem fornecer um percurso para estruturar nosso diálogo: coletivos docentes como espaços de resistência, metodologias em diálogos com 
saberes e matemática como desobediência político-epistêmica. Tais eixos não pretendem estabelecer categorias disjuntas em que enquadraríamos esses estudos, nem têm a pretensão de esgotar suas potenciais contribuições; mas permitem, a partir de suas articulações, evidenciar possibilidades de resistência por meio da opção pela decolonialidade.

Considerar a formação de professoras e professores que ensinam matemática tendo como opção a decolonialidade nos impõe, ainda, o desafio de compreender historicamente o modo como, nos contextos brasileiros, nossos processos formativos são permeados por traços e efeitos da colonialidade. Evidentemente, esse seria um amplo projeto, irredutível às discussões aqui apresentadas e, por isso, nossa intenção é apenas indagar essa formação desestabilizando as narrativas hegemônicas que a historiografia da educação brasileira buscou produzir e consolidar, questionando alguns lugares comuns e olhares de cima que caracterizam os estudos sobre a história da formação de professoras e professores que ensinam matemática. Como destacam Ramalho e Porta (2018), trata-se de um exercício de nomear o que não tem nome, de enfraquecer cada vez mais a produção unívoca da história, recuperando o direito de nomear e de decidir como contar nossas histórias.

\section{Que história(s) da formação de professoras e professores (não) contamos?}

Às vezes, eu temo escrever. Escrever se transforma no medo de não poder escapar de tantas construções coloniais. Neste mundo, eu sou vista como um corpo que não pode produzir conhecimento. Como um corpo sem lugar. Eu sei que enquanto eu escrevo, cada palavra que eu escolho será examinada, e talvez até mesmo invalidada. Então, por que eu escrevo? Eu preciso. Eu estou incorporada em uma história de silenciamentos impostos, de vozes torturadas, línguas despedaçadas, idiomas forçados e discursos interrompidos. Eu estou cercada por espaços brancos onde eu dificilmente posso entrar ou permanecer. Então, por que eu escrevo? Eu escrevo quase como uma obrigação, para me encontrar. Enquanto eu escrevo, eu não sou o "Outro", mas o eu; não o objeto, mas o sujeito. Eu me torno a relatora, e não a relatada. Eu me torno a autora e a autoridade da minha própria história. Eu me torno a absoluta oposição ao que o projeto colonial havia predeterminado. E me torno eu.

Transcrição da videoinstalação Enquanto eu escrevo, de Grada Kilomba.

Em geral, a história da formação de professoras e professores que ensinam matemática no Brasil recebe como marco a incorporação do Instituto de Educação de São Paulo à 
Universidade de São Paulo (USP), em 1934. Esse Instituto - que se tornaria, em 1938, a Secção de Educação da USP - era responsável por conferir formação pedagógica aos estudantes das diversas secções da Filosofia, Ciências e Letras que pretendessem licença para atuar no ensino secundário, em franca expansão.

Acontece que essa narrativa sobre a formação de professoras e professores, além do nítido privilégio que atribui aos centros urbanos e à formação disciplinar e universitária, produz efeitos que, entendemos, mantém nos processos formativos de professoras e professores que ensinam matemática traços da colonialidade, impedindo que diferentes formas de resistência sejam impulsionadas em nome da imposição de compreensões incontestáveis. Nesse sentido, buscaremos nesta seção evidenciar traços e efeitos da colonialidade que essa narrativa hegemônica ajuda a produzir, lendo-a segundo autores que nos auxiliam a desvelar a cumplicidade das instituições sociais, como a Universidade, na perpetuação da colonialidade e a pretensão unívoca dos relatos produzidos no campo da Educação.

Em 2014, comemoraram-se os 80 anos da criação do curso de Matemática da USP, considerado o primeiro no Brasil. Gomes (2016), ao promover uma discussão sobre a criação desse curso como acontecimento fundador da história da formação em nível superior de professoras e professores de matemática, destaca que "um costumeiro fascínio quanto à primazia cronológica e o fato de o curso da USP ser realmente o mais antigo do Brasil podem obscurecer a existência, entre nós, de outras experiências institucionais dotadas de características diferentes, mesmo nas décadas de 1930 e 1940” (p. 430). Como exemplo, a autora cita a experiência da Universidade do Distrito Federal que promovia, diferente de suas congêneres criadas décadas posteriores, uma formação docente articulada diretamente com o ensino secundário, mediante a interação dos estudantes com a escola e a promoção de disciplinas de cunho pedagógico desde o segundo ano do curso.

Além do apagamento de outras histórias da formação de professoras e professores que ensinam matemática que Gomes (2016) nos ajuda a perceber, podemos destacar aspectos dessa narrativa que atuam no estabelecimento de ideários e discursos pedagógicos, identificados aqui como traços e efeitos da colonialidade em processos formativos.

Junto à narrativa hegemônica, que converte o curso de Matemática da USP no brado Terra à Vista! da história da formação de professoras e professores que ensinam matemática no Brasil, diferentes pesquisas destacam que a principal função dos primeiros cursos era a preparação de matemáticos, ficando subordinada à formação do cientista a intenção de formar 
docentes profissionalmente. De fato, a criação das Faculdades de Filosofia, Ciências e Letras no Brasil veio acompanhada de duas funções: por um lado, tinham como propósito desenvolver um conhecimento científico desvinculado da formação profissional; e, por outro, cumpriam o papel de instituições responsáveis pela preparação de professores para o magistério no ensino secundário. Ao que parece, a imbricação dessas duas funções, bem como o ineditismo de se formar cientistas e professores no Brasil, superando a ideia de que "toda escola superior profissional deveria corresponder sempre uma especificidade técnica objetivável em termos de profissão liberal" (SUCUPIRA, 1969, p. 261), contribuíram para que tal subordinação se estabelecesse.

Contudo, o principal efeito dessa subordinação foi a naturalização, no tempo, de que a formação de professoras e professores que ensinam matemática, particularmente dos que atuam nos atuais anos finais do Ensino Fundamental e Ensino Médio, deve vir atrelada à formação do matemático, condicionando nossos processos formativos, tanto conceitualmente quanto institucionalmente, aos espaços físicos e subjetivos ocupados pelos matemáticos profissionais. Assim, as ações políticas que procuram deslocar a formação de professoras e professores desses espaços - seja retirando-os da responsabilidade de Institutos ou Departamentos de Matemática, questionando a expressiva presença da matemática científica nos currículos de Licenciatura ou reivindicando uma identidade docente que não seja construída ao lado da identidade do matemático -, são questionadas e invisibilizadas nos debates sobre a formação de professoras e professores.

Acreditamos que essa naturalização tem a ver com a prevalência de um modelo epistêmico propagado pela modernidade euro-eua-cêntrica, sendo a Universidade o lócus que encarna o pensamento disciplinar e instaura uma organização arbórea de suas estruturas. Segundo Castro-Gómez (2007), ambos, pensamento e organização, favorecem a ideia de que os conhecimentos possuem suas hierarquias, suas especificidades, seus limites epistêmicos, seus princípios definidores de procedimentos e funções. Nessa visão, a Universidade marca intensamente as fronteiras entre os campos do saber, sendo desencorajadas as iniciativas para transgredi-las.

Aqui, parece-nos operar um importante traço da colonialidade: uma hierarquização de saberes direcionada à hierarquização de corpos sociais; uma organização de conhecimentos que coloca o pedagógico não como amadurecimento - ainda que tratado ao final da formação -, mas como qualificável apenas quando o conhecimento matemático, superior, o precede e o 
determina. Assim, o ser professora ou professor estaria epistemologicamente e subjetivamente condicionado ao ser matemático: não pode haver professora ou professor de matemática que desconheça a matemática praticada nos espaços científico-acadêmicos.

Poderíamos tomar como inevitável a subordinação epistemológica da formação de professoras e professores que ensinam matemática à matemática científico-acadêmica, fortemente naturalizada nos processos formativos brasileiros. Entretanto, restar-nos-ia a pergunta: "existe alternativa para decolonizar a Universidade, libertando-a da arborização que caracteriza tanto seus conhecimentos como suas estruturas?” (CASTRO-GÓMEZ, 2007, p. 84, tradução nossa).

Como veremos, diferentes as autoras e autores que contribuíram com este ensaio propõem-se a mostrar que alternativas existem, de modo que essa subordinação não se configure como única possibilidade de relação epistemológica. Seja pela ampliação do campo de visibilidade aberto pela própria epistemologia moderna (FORNER; MALHEIROS, 2019; ZAIDAN, 2019); pela delimitação de lugares de resistência (MATOS; QUINTANEIRO, 2019); pela exposição das relações da formação de professoras e professores com a biopolítica neoliberal (AMARIS-RUIDIAZ; SILVA, 2019); ou pela reelaboração dos sentidos ético, estético e/ou político dessa formação (CAMMAROTA; ROTONDO; CLARETO, 2019; GOMES; CHISTÉ; GONDIM, 2019; SANTOS; CORRÊA, 2019), esses estudos enfrentam essa subordinação pela reconstrução de sentidos, projetos e práticas vinculadas à formação de professoras e professores, descortinando diferentes efeitos da colonialidade, na intenção de superá-los.

Outra implicação da história da formação de professoras e professores que ensinam matemática no Brasil, ainda ligada ao seu marco fundador (o curso de Matemática da USP), é a construção da ideia da Universidade como espaço privilegiado de produção, legitimação e regulação de conhecimentos. Como destacam Fernandes, Araújo e Cosenza (2019), a criação das Faculdades de Filosofia, Ciências e Letras no Brasil veio acompanhada da proposição de uma identidade profissional docente caracterizada pela similaridade entre a estrutura e os modos de organização e funcionamento dos cursos, e da elaboração de um conjunto de procedimentos direcionados a normatizar a formação, promovendo uma série de regulações, formais ou não, que viabilizassem a manutenção desses cursos e a circulação desses novos profissionais. A Universidade se converteu não só no lócus de produção, legitimação ou regulação de conhecimentos pedagógicos, como também no núcleo vigilante do processo educacional, 
direcionado aos interesses de progresso material da nação e de construção moral da sociedade em diferentes períodos.

Assim, a opção decolonial nos impele compreender e romper com a subserviência da Universidade - e, consequentemente, da formação de professoras e professores que ensinam matemática por ela praticada - à superioridade e aos padrões culturais, sociais, políticos, territoriais, raciais e de gênero e sexualidade da modernidade euro-eua-cêntrica. Na medida em que cria, legitima e reproduz o saber que busca conformar a colonialidade, as "universidades se tornam instituições decisivas para produzir um conhecimento oficial com o qual se podem considerar ilógicas e injustas as exigências daqueles que estão sendo explorados e escravizados; para inferiorizar e destruir outras epistemologias e saberes rivais" (SANTOMÉ, 2017, p. 114115).

Nessa direção, a proposição de uma identidade docente, ainda que inicialmente construída por meio de uma ação política e jurídica empreendida pela conversão da Universidade em lócus de sua constituição, se consolidou e se reproduziu em meio a processos que procuraram converter as experiências de dominação epistemológica e ontológica em ideais de progresso, justiça e liberdade. A decisão sobre os diferentes aspectos da formação de professoras e professores ficou, então, a cargo de um grupo dedicado a introjetar uma narrativa que justificasse a si próprio como único e necessário; de modo que outros grupos, à margem, tiveram e ainda têm pouca ou nenhuma expressão na construção desses cenários de formação, permanecendo subalternizados na qualificação de seus sujeitos, saberes e práticas nos mais diversos processos formativos.

As autoras e os autores que contribuíram com este trabalho, de modos mais ou menos propositivos, indicam possibilidades de construção de resistências individuais e coletivas junto às macro e micropolíticas que cerceiam a formação de professoras e professores, especialmente as políticas de identidade. Entre discussões sobre a constituição de identidades profissionais em coletivos como caminhos de formação, ativismo e resistência (NACARATO; CUSTÓDIO; MOREIRA, 2019; LOPES, 2019; DE PAULA; CYRINO, 2019) ou sobre a reivindicação e reconfiguração de processos formativos institucionais a partir da presença de outros sujeitos, particularmente indígenas (TOMAZ, 2019), esses estudos desconstroem a narrativa hegemônica sobre as identidades docentes, evidenciando outros espaços destinados a subverter os ideários e discursos pedagógicos habituais que permeiam e cerceiam o ser professora ou professor. 
Entendemos que as contribuições discutidas neste ensaio têm um papel importante de nos recordar que a narrativa instituída sobre a formação de professoras e professores que ensinam matemática não é a única possível. Eles nos obrigam a voltar a nossa atenção ao legado euro-eua-cêntrico que configura nosso entorno educativo - e, particularmente nas intenções deste ensaio, formativo -, buscando a reivindicação de uma história que parta da suspeição dos efeitos que essa narrativa produz em nós mesmos, nossa inevitável colonialidade. Escrever com esses estudos significa colocar-se em relação com eles, descortinando e deixando-se afetar e dizer a partir dos diferentes traços de colonialidade que evidenciam e dos caminhos de resistência que reivindicam.

\section{Tratamentos de não-existência em identidades profissionais docentes}

Em tempos de reforma, é, essencialmente, a identidade dos professores que está em jogo.

(GELLERT; ESPINOZA; BARBÉ, 2013, p. 543 apud DE PAULA; CYRINO, 2019)

Walsh (2008) demarca a colonialidade do ser como a dimensão ontológica da colonialidade, que se manifesta por meio da inferiorização, da subalternização do sujeito e de suas capacidades cognitivas. A constituição de grupos subalternizados permite que esses ocupem posições sociais e de trabalho que não são escolhidas por eles, de cujas funções sociais eles podem nem mesmo ter consciência, e que servem a um projeto político e econômico de dominação. A colonialidade do ser é, em geral, associada à desumanização de grupos sociais por conta de sua cor ou de suas raízes, descrita por Fanon (2008) como o "tratamento da nãoexistência”. Entretanto, processos de colonialidade do ser também podem ser reconhecidos em outros grupos que são relegados a lugares sociais subalternizados a serviço de um projeto de poder político e econômico, quando as identidades dos sujeitos, enquanto membros desses grupos, são desqualificadas ou inferiorizadas. Isto é, reconhecemos esses processos de colonialidade com base no papel que a posição social imposta a esses grupos desempenha no projeto de poder hegemônico.

A desqualificação do trabalho de professoras e professores, como uma atividade profissional, tem sido denunciada por várias autores e autores. Tardif, Lessard e Lahaye (1991) apontam o que, em uma primeira análise, pode ser interpretado como uma contradição. Por um lado, "professores ocupam uma posição estratégica no interior das relações complexas que 
unem as sociedades contemporâneas aos saberes que elas produzem e mobilizam para diversos fins" (p. 216); por outro, "na medida em que a produção de novos conhecimentos tende a se impor como um fim em si mesmo [...], as atividades de formação e de educação parecem passar, progressivamente, para o segundo plano" (p. 217). Possivelmente, seja pela própria posição estratégica ocupada por professoras e professores nas sociedades contemporâneas, que processos de colonialidade do ser operem para relegar sua identidade como profissionais a um plano inferior. O ser professora ou professor na educação básica é com frequência rotulado socialmente como um ofício essencialmente prático ou tácito, algo que qualquer um pode fazer, que não requer nenhum tipo de saber específico, que resta a alguém que não teve sucesso em outras atividades mais prestigiadas, portanto, alguém "com capacidades cognitivas inferiores" - um campo de atuação desprovido de uma epistemologia própria.

Diversas autoras e autores convergem com a identificação de uma subordinação epistemológica da formação de professoras e professores aos conhecimentos científicos hegemônicos, como discutimos de uma perspectiva histórica na seção anterior. Moreira e Ferreira (2013) apontam uma vertente subjacente a pesquisas recentes, em que "se valoriza preponderantemente o Conhecimento do Conteúdo na prática docente na escola básica e na definição do lugar da matemática na formação do professor" (p. 27). Cochran-Smith e Lytle (1999) identificam três concepções radicalmente diferentes de formação de professores, que incluem entendimentos sobre relações necessárias e/ou potenciais entre conhecimento e prática profissional. Dentre essas, as autoras se referem ao conhecimento-para-prática como uma concepção segundo a qual acadêmicos e especialistas geram os conhecimentos formais e teorias que professoras e professores devem aprender para utilizar ou aplicar em suas práticas profissionais. Os espaços de aprendizagem profissional docente se restringiriam, então, a cursos conduzidos por especialistas da universidade. Como observam Giraldo et al. (2018), as vertentes e concepções apontadas por essas autoras e autores

demarcam uma crítica com respeito à existência de uma concepção tácita e disseminada de que os saberes necessários para ensinar matemática na escola básica se situam em um lugar externo ao próprio espaço profissional e cultural da sala de aula, e que a autoridade sobre tais saberes cabe a grupos dos quais o professor que atua na escola básica está excluído. Isto é, caberia a grupos [...] cujos membros podem não atuar na escola básica - e nem mesmo reconhecer a legitimidade dos saberes emergentes da prática - ditar aos professores como devem ou não ensinar matemática na escola básica. (GIRALDO et al., 2018, p. 188)

Assim, produzem-se narrativas sobre saberes necessários para professoras e professores, nas quais esses sujeitos não são as primeiras pessoas. Matos (2019) afirma que certas 
concepções de saberes docentes manifestam traços de colonialidade na medida em que, no âmbito de um projeto de poder político que consolida a ciência como campo de referência de saberes, "concebem a escola como um lugar estratégico ou um lugar ermo, propícios ao progresso da matemática como ciência e à percepção social de valorização do conhecimento matemático" (p. 147).

Recorremos à literatura de pesquisa em formação docente para denunciar a invisibilização de uma epistemologia própria ao ser professora ou professor na educação básica, e da autoridade de professoras e professores sobre seus próprios saberes profissionais. Porém, mesmo quando se discutem saberes e práticas específicos da atividade profissional docente na escola básica, seguimos interpelando essas autoras e autores: em que estão referenciados esses saberes e práticas?

Podemos argumentar, portanto, que, no contexto das práticas de professoras e professores que ensinam matemática na educação básica, a colonialidade do ser opera de forma articulada com a colonialidade do saber, descrita por Walsh (2008) como a imposição das epistemologias e racionalidades hegemônicas (referenciadas em culturas brancas e europeias) como única forma de conhecimento, e na desconsideração de sabedorias outras. Segundo a autora, a colonialidade do saber está profundamente enraizada no sistema educativo, desde a escola até a universidade, onde o conhecimento europeu é elevado e legitimado como o marco científico-acadêmico-intelectual.

Fiorentini (2013) destaca três modalidades de comunidades de aprendizagem e investigação de professores, no que concerne a relação escola-universidade: acadêmicas (monitoradas pela universidade); escolares (monitoradas pela escola); fronteiriças (sem território definido de controle). $\mathrm{O}$ autor ${ }^{4}$ observa que, dentre as comunidades acadêmicas, algumas são colonizadoras da prática escolar; e dentre as comunidades escolares, algumas são dispostas a serem colonizadas.

A opção pela decolonialidade pode situar essa discussão em uma perspectiva mais ampla na qual, como observa Walsh (2008), tanto escola como universidade são colonizadas e também têm sido instrumentos centrais em um projeto de colonialidade do saber, que legitima conhecimentos hegemônicos e invisibiliza sabedorias outras. Nesse projeto, processos de

\footnotetext{
${ }^{4}$ Embora os termos colonizado e colonizador no estudo de Fiorentini não tenham referência explícita aos sentidos de colonialidade a que nos referimos neste ensaio, reconhecemos convergências, na medida em que ambos buscam evidenciar relações de poder em contextos de formação e práticas docentes. 
colonialidade do ser operam relegando professoras e professores a uma posição social inferiorizada, em que suas identidades profissionais são enfraquecidas, sua atuação é reduzida a uma dimensão tecnicista e tácita, e a autoridade sobre os saberes de referência para essa atuação é outorgada a atores externos a seus próprios espaços profissionais. Nesse contexto, professoras e professores podem nem mesmo ter plena consciência política das funções sociais de seu trabalho, ou de como essas funções sociais desempenham um papel no projeto amplo de colonialidade por meio da imposição de epistemologias hegemônicas.

Dentre as autoras e autores que contribuíram com este trabalho, De Paula e Cyrino (2019) discutem perspectivas para o conceito de identidade profissional de professoras e professores que ensinam matemática, com base em um inventário, relativo no período entre 2006 e 2016, de dissertações de mestrado e de teses de doutorado (no Brasil, nas áreas de Educação e de Ensino), bem como de artigos científicos (nacionais e internacionais). A autora e o autor destacam, como elementos emergentes desses estudos, o reconhecimento das influências sócio-político-culturais nos movimentos de constituição de identidades profissionais de professoras e professores que ensinam matemática e, mais especificamente, a compreensão de que contextos de regulação e de perda de direitos são nocivos a esses movimentos - o que interpretamos como processos de colonialidade do ser, que operam de forma articulada com a colonialidade do saber. De Paula e Cyrino (2019) elencam aspectos considerados danosos ao movimento de constituição da identidade profissional de professoras e professores que ensinam matemática nos estudos inventariados:

as modificações causadas em/por contextos reformistas como as ações promotoras de
cursos/treinamentos em grande escala (característicos desse processo), a elaboração
(ou defesa) de rankings de instituições escolares, bem como a existência de políticas
alinhadas a valorizar a meritocracia como um dos critérios para a remuneração
profissional. (DE PAULA; CYRINO, 2019, p. 646)

De Paula e Cyrino (2019) destacam, ainda, que possibilidades de resistência envolvem necessariamente elementos como a autonomia profissional, a prática reflexiva, o trabalho colaborativo, a criatividade e a alteridade, que são legitimados pelo comprometimento com práticas orientadas por reflexões sobre democracia, ética, justiça social, solidariedade e compromisso político. Interpretamos essas possibilidades como movimentos de decolonialidade sustentados na constituição de identidades profissionais docentes pautadas pela tomada de consciência política por parte de professoras e professores sobre o papel social de 
sua atividade profissional - movimentos de (re)existência que podem produzir narrativas sobre a formação de professoras e professores nas quais eles próprios são as primeiras pessoas.

\section{Coletivos docentes como espaços de resistência}

Os movimentos de (re)existência que apontamos na seção anterior podem ser construídos a partir da constituição em grupos ou comunidades em que professoras e professores buscam refletir e reconstruir seus saberes e práticas profissionais. Esse tem sido um foco importante da literatura de pesquisa recente em Educação Matemática no Brasil (e.g. FIORENTINI, 2013), com base em diferentes prismas teóricos - a que, neste ensaio, nos referiremos de forma genérica por coletivos docentes (sem referência a uma afiliação teórica específica).

Entretanto, mesmo coletivos docentes podem não ultrapassar uma perspectiva essencialmente cooperativa, em que o foco permanece em como a vivência no grupo contribui para o desenvolvimento de saberes docentes de cada participante individualmente. Coletivos docentes podem avançar para uma perspectiva colaborativa, quando o foco abrange as formas como estes se constituem como coletivos e a construção de saberes e de posturas didáticas compartilhadas por seus participantes. $\mathrm{O}$ trabalho em coletivos docentes pode ainda atingir uma perspectiva político-cultural, em que cada participante passa a entender a si próprio e suas ações, escolhas e posturas, como sujeito e como profissional, em contextos mais amplos de culturas profissionais docentes, em uma dimensão política que situa essas ações, escolhas e posturas nas funções sociais de seu trabalho.

Consideramos que esses movimentos de resistência só podem se estabelecer, de fato, em coletivos docentes em uma perspectiva político-cultural. Assim, os caminhos de resistência podem ultrapassar a centralidade em cada professora ou professor, em cada sala de aula, para a conversão da docência como ação coletiva e politicamente engajada. Pensamos que somente a partir do entendimento de suas ações, escolhas e posturas em contextos políticos e sociais mais amplos, professoras e professores podem (re)existir como profissionais, fortalecer suas identidades e tomar para si a primeira pessoa das narrativas sobre seus próprios processos formativos e sobre suas práticas, bem como a autoridade sobre seus próprios saberes - em um movimento decolonial. 
Algumas autoras e autores que contribuíram com este trabalho apresentam possibilidades de resistência que, em nossa intepretação, alinham-se com uma perspectiva político-cultural do trabalho em coletivos docentes. Essas possibilidades são, de forma geral, construídas a partir do deslocamento do lócus de formação, que deixa de estar centrado na universidade como espaço privilegiado da produção das identidades profissionais docentes.

Nacarato, Custódio e Moreira (2019) discutem a constituição de um grupo de mulheres e professoras que ensinam matemática (licenciadas em matemática e pedagogas) como espaço de formação e de resistência à imposição de uma lógica centrada na produção econômica, no racionalismo técnico e no alcance de objetivos, e não na preservação de valores e aprendizagens dos atores da escola. As autoras destacam o papel do grupo na produção de táticas (no sentido de Michel de Certeau) que podem transformar incertezas em lugares legíveis, para enfrentar estratégias articuladas por agentes externos com foco no controle do trabalho das professoras, a serviço dessa lógica. O grupo se configura como uma possibilidade de (auto)formação, como alternativa a modelos de formação que impõem propostas para a sala de aula elaboradas por especialistas externos, cabendo às professoras apenas a reprodução. Assim, as professoras retomam para si a condução da própria formação, a autoria dos próprios saberes - o que leva, por meio da ressignificação das experiências, a uma tomada consciência de suas práticas, de sua realidade, de limitações e de possibilidades.

Nessa direção, Lopes (2019) aponta o trabalho em grupos colaborativos como possibilidade de resistência à mercantilização da profissão docente, que gera contradições sobre sua natureza, sobre a identidade e o desenvolvimento profissional. Com base nos estudos da pesquisadora Beatriz D’Ambrosio, a autora aponta uma possibilidade de reconfiguração do conceito de professor pesquisador, como "um profissional que assume o confronto com seus dilemas e desafios, e, apoiado em uma dinâmica colaborativa, com seus pares, redimensiona sua identidade profissional e exerce sua agência" (LOPES, 2019. p. 600). Lopes (2019) afirma ainda que o exercício da agência implica que professoras e professores sejam capazes de autorregular a suas próprias ações, e que a construção de suas identidades profissionais também seja controlada por eles próprios - e não por agentes externos que procuram moldá-los.

Entendemos que os estudos de Nacarato, Custódio e Moreira (2019) e de Lopes (2019) são convergentes na afirmação da perspectiva de coletivos docentes que chamamos de políticocultural, segundo a qual as professoras e os professores assumem para si a autoria dos próprios processos formativos e tomam consciência do papel social e político da própria atividade 
profissional. As autoras também convergem na afirmação de interrelações entre essa tomada de consciência por professoras e professores e posturas docentes mais comprometidas com a equidade e com a justiça social. Nesse sentido, Nacarato, Custódio e Moreira (2019) comentam que:

\begin{abstract}
As narrativas das professoras foram revelando a constituição de práticas problematizadoras, isto é, práticas pautadas na dialogicidade em que elas colocam os alunos, o tempo todo, no movimento de: questionar, levantar e validar hipóteses, compartilhar e complementar ideias, argumentar e posicionar-se em relação à ideia do outro. Essa cultura de aula de matemática empodera os alunos, visto que o conhecimento matemático lhes possibilita um posicionamento crítico como uma forma de leitura e intervenção no mundo. (NACARATO; CUSTÓDIO; MOREIRA, 2019, p. 531)
\end{abstract}

Também nessa direção, Lopes (2019) observa que a vivência no grupo colaborativo leva professoras e professores a assumir uma postura de profissional ativista, caracterizada a partir dos estudos das pesquisadoras Susan Groundwater-Smith e Judyth Sachs como um profissional que "está preocupado em reduzir ou eliminar a exploração, a desigualdade e a opressão, em uma busca constante pelo desenvolvimento de uma identidade profissional que esteja profundamente enraizada nos princípios de equidade e justiça social" (LOPES, 2019, p. 602). A autora comenta, ainda, que:

O movimento em um grupo colaborativo ocorre por meio da consonância entre a identidade e a prática, favorecendo uma agência efetiva. Ao se inserir nesse movimento, o professor se assume como profissional ativista e toma como eixos centrais em suas ações profissionais a confiança, o respeito, a responsabilidade, a colaboração e a solidariedade (SACHS, 2000).

Interrelações entre uma tomada de consciência por professoras e professores sobre o papel social da profissão e uma postura docente comprometida com a justiça social emergem ainda do levantamento de estudos apresentado por De Paula e Cyrino (2019). Para os autores, tais estudos podem contribuir "com reflexões éticas, filosóficas e políticas [...] relacionadas a promoção/reconhecimento de que vivemos em uma sociedade plural, carente de justiça social, alteridade e investimentos em políticas públicas" (p. 637), que podem ajudar professoras e professores "a assumirem compromisso político, social e cultural, necessários para o desempenho de suas funções na busca de uma sociedade com equidade social” (p. 637).

Sob essa perspectiva, a reinvindicação por professoras e professores da primeira pessoa nas narrativas sobre seus processos formativos pode abrir caminhos para práticas docentes menos subordinadas aos mecanismos de controle de um projeto político e econômico de dominação e mais comprometidas com a justiça social. Assim, podem-se abrir fissuras, lugares 
de potência em que outros atores cujos saberes têm sido invisibilizados nos contextos da educação formal - os próprios estudantes, especialmente aqueles pertencentes a grupos subalternizados e historicamente excluídos - também reivindiquem a primeira pessoa nas narrativas sobre os processos formativos.

\section{Metodologias em diálogos com saberes}

Além dos processos de constituição de identidades docentes, podemos considerar outros caminhos de resistência à colonialidade que marca os processos de formação de professoras e professores que ensinam matemática. Por meio de ações metodológicas ligadas ao ensino, fissuram-se tanto os conhecimentos mobilizados nos processos formativos quanto as instituições responsáveis por esses processos, como a Universidade ou a escola. Em ambos os casos, está em jogo, entendemos, tentativas de decolonização desses espaços pela promoção do diálogo de saberes em sua coexistência no tempo e no espaço.

Na proposição dessa decolonização, Castro-Gómez (2007) indica o diálogo como forma de gerar e gerir espaços em que distintos saberes possam (re)existir. Contudo, o próprio autor enfatiza a dimensão utópica de tal projeto dado o ordenamento epistêmico atribuído aos diferentes grupos socioculturais no tempo, que qualifica os conhecimentos produzidos em grupos subalternizados como anedóticos, superficiais, rupestres ou, em qualquer caso, como pertencentes a um passado em via oposta ao progresso. Nesse sentido, "ainda que um médico indígena seja contemporâneo de um cirurgião que estudou em Harvard, ainda que este último possa cumprimentá-lo e compartilhar com ele um café, $[\ldots]$ ele seria classificado como um habitante do passado, como um personagem que produz um tipo de conhecimento 'orgânico', ‘tradicional' e 'pré-científico"” (CASTRO-GÓMEZ, 2007, p. 87, tradução nossa).

A intenção de decolonização pelo diálogo de saberes passa, então, pela coexistência da pluralidade, superando o distanciamento provocado por fronteiras epistemológicas que não só as hierarquizam por sua legitimidade, mas por sua temporalidade e espacialidade; e afirmando positivamente a contaminação e a aproximação entre os saberes produzidos por diferentes grupos socioculturais. No âmbito da formação de professoras e professores que ensinam matemática, esse diálogo pode ser promovido ao se revisitarem metodologias de ensino, colocando-as a serviço da ampliação das relações entre os conhecimentos presentes ou ausentes nos processos formativos. Esse procedimento, que entendemos como uma conjugação 
epistêmica, que indica os sujeitos, espaços e tempos das diferentes formas do conhecimento que participam da formação de professoras e professores, pode ser favorecido por ideias como a de transdisciplinaridade.

Dentre os autores que contribuíram com este ensaio, Zaidan (2019), partindo de inquietações que interpretamos como efeitos de colonialidade presentes na formação de professoras e professores que ensinam matemática, particularmente os que promovem a "matemática como conhecimento rigidamente estabelecido, pautado na lógica transmissiva de seu ensino, em avaliações seletivas e classificatórias, como parte de um modelo que reforça as diferenças econômicas e sociais, distantes de uma expectativa de formação democrática e inclusiva", propõe a transdisciplinaridade como caminho de resistência à "dominância histórica de paradigmas da formação docente focados em conhecimentos disciplinares” (p. 14). Essa resistência, como comenta a autora, atua em um duplo sentido:

\begin{abstract}
Primeiro, porque a matemática tem um conjunto de procedimentos e registros, oferecendo um enorme arsenal que pode ser relacionado com áreas diversas, para temas diferenciados, capazes de apoiar práticas e ações investigativas. Segundo, pelo interesse, no âmbito da educação matemática, de atuar para uma formação que amplie a capacidade de pensar e analisar das crianças, jovens e adultos, especialmente no entendimento das questões que cercam a sociedade geral e local, desempenhando um papel de conhecimento engajado em questões sociais. Os conteúdos matemáticos podem também atuar para valorização do estudo de temas, pela importância que a área abrange, socialmente se referindo, pelo valor, a ela, atribuído nas avaliações escolares e na formação geral dos sujeitos. (ZAIDAN, 2019, p. 516-517)
\end{abstract}

A perspectiva transdisciplinar permite-nos, então, indicar que qualquer delimitação institucional do que venha a ser matemática carrega, em si, interesses, direcionamentos e intenções, ainda que ocultados sob o pretexto da neutralidade. Os processos formativos que derivam dessa perspectiva podem contribuir para desfazer laços de colonialidade que instituem marcos disciplinares, às vezes específicos e concretos a ponto de serem excludentes entre si, reivindicando as diferenças evidenciadas na contaminação e na aproximação entre diferentes saberes.

Contudo, é importante pontuar que a defesa do uso da matemática para a promoção de outros saberes, dada sua valorização e reconhecimento social, pode reafirmar a hierarquização combatida por propostas pautadas no diálogo. Devemos participar do jogo cuja regra determina que um dado saber, para se afirmar, precisa mobilizar a matemática? O que deveria ser considerado, o valor atribuído à matemática ou o papel periférico e simplista que ela assume como linguagem, procedimento ou registro de questões tão complexas da vida social? Entendemos que enfrentar essas questões pode contribuir com um projeto de decolonização da Perspectivas da Educação Matemática - INMA/UFMS - v. 12, n. 30 - Ano 2019 
Universidade ao considerar, particularmente na formação de professoras e professores que ensinam matemática, possibilidades de conjugação epistêmica que diminuam a posição assimétrica ocupada pelos saberes que dessa formação participam.

Outro ponto de atenção, mais ligado à formação docente, refere-se ao uso da transdisciplinaridade como tentativa de redisciplinar as universidades latino-americanas, especialmente nos movimentos de neoliberalização do ensino superior. Segundo Walsh (2012), esse processo sustenta-se na afirmação de novos domínios do conhecimento e de verdades por eles produzidas, "fazendo que o euro-eua-centrismo se fortaleça como 'o lugar' do conhecimento" (p. 214). Assim, um passo além da transdisciplinaridade exigiria a reivindicação de perspectivas de conhecimento, e não apenas dos conhecimentos, provenientes de cenários e sujeitos nem sempre ligados à academia, questionando os pressupostos estritamente acadêmicos e disciplinares que a acompanham. Sobre essa discussão, compartilhamos o interesse apontado por Walsh (2012):

\begin{abstract}
Nosso interesse não é "facilitar agendas ou agenciamentos culturais para grupos subalternos e movimentos sociais", promover "ativismo" ou "incluir outros conhecimentos", mas construir um projeto político-intelectual outro, aprender a pensar desde, junto e com a realidade latino-americanos e seus atores [...], incentivando dessa maneira convergências, articulações e interculturalizações que fazem uma academia comprometida com a própria vida. Tal perspectiva não elimina ou nega o conhecimento concebido desde a Europa ou América do Norte - usualmente referido como "universal" - ou seus pensadores, mas faz parte de um corpo e olhar mais amplos, que sustentam o multiculturalismo e as distinções importantes em seus locais de enunciação. (WALSH, 2012, p. 214-215).
\end{abstract}

Além da superação da fragmentação do conhecimento como efeito da colonialidade, podemos pensar caminhos de resistência aos dispositivos neoliberais que se aproximam e se instituem junto aos diferentes processos formativos. Forner e Malheiros (2019), ao se colocarem em resistência à cultura da performatividade que se caracteriza pela aproximação da globalização - e, estendemos, do neoliberalismo - ao meio educacional, discutem as contribuições da Modelagem como caminho que, pela matemática, potencialize a formação de sujeitos críticos e reflexivos, atentos e capazes de modificar os contextos em que estão inseridos. Mais uma vez, a ideia de diálogo de saberes em sua coexistência no tempo e no espaço surge como imperativo para romper com dimensões coloniais que permeiam os processos formativos dos quais professoras e professores que ensinam matemática participam.

Nesse estudo, a partir das falas de um curso de formação produzido com (e não para) professoras e professores que ensinam matemática na rede pública do estado de São Paulo, verifica-se "que cada vez mais a cultura escolar caminha para o tecnicismo em detrimento de Perspectivas da Educação Matemática - INMA/UFMS - v. 12, n. 30 - Ano 2019 
fatores de cunho mais humano, contradizendo as ideias apresentadas nos documentos oficiais" (FORNER; MALHEIROS, 2019, p. 545). Entendemos que essa contradição não evidencia um contrassenso, mas a própria produção do que Santomé (2017) caracteriza como um novo currículo neoliberal. Mobilizado e materializado por grandes grupos empresariais e financeiros, esses currículos buscam adequar as políticas educativas aos interesses desses grupos, fabricando acordos por meio de uma mudança discursiva que busca capturar nos documentos oficiais terminologias próprias dos coletivos sociais que, especialmente nas décadas de 1980/90 na América Latina, lutaram para a superação, através da educação, de uma condição social classista, racista, sexista, homofóbica e segregadora. Assim,

\begin{abstract}
Implicitamente, na maioria dos casos, assume-se que nossas sociedades são justas, inclusivas, democráticas e que reina uma autêntica igualdade de oportunidades. Com esse tipo de pressuposto, é mais fácil perder de vista objetivos e medidas educacionais que visam ajudar a compensar e a superar desigualdades; não se fala explicitamente e se relega esse tipo de análise para que, com ele, pouco a pouco, esqueça de se perguntar se o que se demanda dos alunos em sua passagem por escolas e salas de aula contribui que possam compreender, valorar e intervir em sua comunidade e no mundo, em geral. Esses tipos de propostas e reformas não são apresentadas como opções frente a outras possíveis, mas como as únicas reais. (SANTOMÉ, 2017, p. 81, tradução nossa)
\end{abstract}

Compreendemos, então, que a reavaliação de metodologias, além da intenção de favorecimento da emancipação dos sujeitos da educação, promovendo transgressões à ordem estabelecida nos âmbitos curricular e institucional, atuam como caminho de resistência à insistente produção do humano neoliberal e neocolonial, pessoa convertida em empreendedora de si mesma, que se culpabiliza por sua condição e que minimiza a importância das políticas de superação das desigualdades vigentes. Trata-se de uma resistência ao amplo projeto que perpetua e conforma a colonialidade do poder, um modo incisivo de exercer, através de ideais como progresso, justiça e liberdade, a hierarquização de corpos e de legitimar a exploração de recursos naturais e humanos.

Ter em vista essas discussões junto à formação de professoras e professores que ensinam matemática, em seus diferentes espaços de desenvolvimento e atuação, é contribuir com uma decolonização de processos formativos e escolares marcados, na atualidade, pela consolidação do projeto neoliberal e neocolonial em educação. Aqui, a matemática tem se convertido como principal agente para a afirmação desse projeto, sendo o alvo e o tributo das políticas curriculares, avaliativas e de identidade. Promover, pela matemática, outros caminhos de resistência é lutar contra a desesperança, a passividade, o conformismo e a resignação que marcam a posição de tantas professoras e professores frente às instituições democráticas; Perspectivas da Educação Matemática - INMA/UFMS - v. 12, n. 30 - Ano 2019 
permitindo também, por suas metodologias, pensar e construir ações mobilizadoras e transformadoras do atual curso da história.

\section{De quem é, para quem é e em que está referenciada a formação de professoras e professores?}

Estamos aqui com toda verdade de nossa Tradição. Sem rancor, sem raiva. Mas, também não estamos comemorando nada. Esta não é nossa comemoração. Apesar de toda distância e dificuldade, viemos porque temos que falar com vocês. [...] Que esta revelação possa despertar o encontro com a verdadeira natureza que está dentro de vocês, que possa fortalecer o espírito criador contra o avanço do lado obscuro. Estamos fazendo um ritual de passagem para transformar este lugar num país onde nosso povo possa permanecer vivendo com sua identidade e patrimônio, dentro de sua tradição.

Trecho de carta enviada por indígenas das etnias Xavante e Mehinaku, em 2000, aos presidentes de Brasil e de Portugal, na época Fernando Henrique Cardoso e Jorge Sampaio, em razão da "comemoração" dos 500 anos do "descobrimento" do Brasil.

Os estudos que destacamos nas duas seções anteriores apontam caminhos de resistência a projetos de dominação política e econômica, que impõem processos de colonialidade de seres e de saberes. Esses caminhos - que se constroem a partir da tomada para si por professoras e professores das primeiras pessoas das narrativas sobre seus próprios processos formativos e práticas, seja pela constituição de coletivos docentes em uma perspectiva político-cultural (LOPES, 2019; NACARATO; CUSTÓDIO; MOREIRA, 2019), ou pela afirmação de metodologias que deslocam a formação (FORNER; MALHEIROS, 2019; ZAIDAN, 2019) provocam tensionamentos nos espaços e modelos institucionalizados de formação de professoras e professores: de quem é, para quem é e em que está referenciada a formação?

De quem é a formação? Quem determina o que deve ou não estar na formação, e como esta deve ou não ser estruturada? Para quem é a formação? Quem são os sujeitos da formação? Quem são as professoras e os professores que se intenciona formar? Para que projeto político de escola essas professoras e professores são formados? Para que aprendizes são essa(s) escola(s)? São essas escolas cuja função é legitimar os saberes hegemônicos e apagar outras sabedorias, ou são essas escolas que reconhecem e incorporam sabedorias outras, que se (re)constrói para e com sujeitos de grupos subalternizados? Em que está referenciada a 
formação? Que saberes, práticas, racionalidades, sabedorias e culturas a formação legitima, mobiliza ou pretende produzir?

Esses tensionamentos expõem fissuras que podem se constituir em lugares de resistência e de potência, nos quais os atores dos espaços educacionais institucionalizados docentes e aprendizes, especialmente aquelas e aqueles de grupos sociais subalternizados ou historicamente excluídos - reivindicam a primeira pessoa das narrativas que produzem sentidos para esses espaços.

O estudo de Tomaz (2019) explicita ainda mais esses tensionamentos ao discutir a formação dos professores indígenas em um curso de licenciatura intercultural, na habilitação em Matemática, que "possibilita que outras formas de saberes e práticas, associados a grupos historicamente excluídos e subalternizados, como são os indígenas, ganhem e provoquem mudanças na atividade de formação" (p. 660).

Os processos escolares e formativos vinculados à matemática são caracterizados por uma cultura de ensino de matemática marcada pela identificação dos mais capazes ou mais inteligentes e pela separação desses daqueles considerados fracos ou atrasados (GIRALDO, 2018). Além disso, essa noção de "inteligência" é determinada por racionalidades hegemônicas, segundo as quais o estereótipo de genialidade matemática está associado a corpos de homens, brancos, europeus, heterossexuais e cisgêneros. Especificamente na formação de professoras e professores que ensinam matemática, ainda que não exista, diretamente, a discriminação ou a extinção de corpos pautada em categorias de raça, gênero, etnia ou território - mesmo que essas categorias estejam implicitamente relacionadas à matemática -, há uma prevalência da constituição de identidades profissionais predeterminadas pelo projeto colonial, promovendo a separação, a seleção e a exclusão de sabedorias que não estejam alinhadas às racionalidades hegemônicas. Pode-se entender esses processos a partir de uma articulação entre os eixos de colonialidade do saber e do poder, este último caracterizado por Quijano (2000) como o estabelecimento de um sistema de classificação social baseada em uma hierarquia racial e de gênero, e na formação e distribuição de identidades sociais de superior a inferior: brancos, mestiços, índios, negros.

Discussões com foco em contextos educacionais para grupos subalternizados ou historicamente excluídos, como é o caso do estudo de Tomaz (2019), nos desafiam a (re)pensar espaços e modelos de formação de professoras e professores que ensinam matemática sob a ótica de diversos questionamentos. Como construir processos formativos em que o 
protagonismo seja de outros atores, especialmente aquelas e aqueles massacrados como colonialismo ou subalternizados pela colonialidade? Como considerar, nesses processos, sabedorias outras, diferentes daquelas previstas pelo projeto colonial? Como construir processos formativos que privilegiem a constituição de identidades profissionais docentes conscientes e politicamente resistentes à colonialidade que permeia os contextos educacionais institucionalizados? Em que medida podemos deslocar e torcer as instituições formativas para legitimarem sabedorias outras, abriguem outros sujeitos, comunidades e coletivos, reconhecendo sua centralidade na produção da educação (matemática) brasileira?

O estudo de Tomaz (2019) nos evidencia que existem sabedorias outras, e que existe uma formação pautada por essas sabedorias. A autora comenta que:

Um dos aspectos mais significativos desse curso é garantir a autoria indígena nas atividades desenvolvidas, concretizada, principalmente, nas pesquisas realizadas pelos estudantes sobre seu próprio povo para o trabalho de conclusão de curso. Ou seja, os componentes curriculares assumem a pesquisa como suporte de formação. É nesse contexto que o curso ocorre em espaços/tempos diferenciados possibilitando aos licenciandos a imersão no universo acadêmico, a universidade, e aos professoresformadores a imersão no universo indígena, com sua presença nos territórios. (TOMAZ, 2019, p. 658)

Tomaz (2019) afirma ainda que "diferentes lógicas de vida, linguagens e outros sujeitos que norteiam a ação docente indígena tensionam a proposta de formação dos indígenas que vão ensinar matemática nas suas comunidades" (p. 659); enunciando, ainda, diversas questões que emergem desse contexto:

\begin{abstract}
Quais matemáticas são produzidas e socializadas neste curso? Qual o papel das atividades de sala de aula para ampliar o repertório de práticas em que se fala de ou usa matemática e para possibilitar aprendizagens no contexto da formação de professores indígenas? Que tensões ocorrem na formação, quando os estudantes indígenas tentam estabelecer relações entre práticas da tradição indígena e práticas da matemática científico acadêmica? Como a interculturalidade opera na proposta de formação intercultural para educadores indígenas da UFMG, quando os estudantes desenvolvem pesquisas para seus trabalhos de conclusão de curso? Como são criados instrumentos metodológicos para lidar com os desafios da atividade de pesquisa pelos estudantes quando diferentes racionalidades entram em contato? (TOMAZ, 2019, p. 659)
\end{abstract}

As relações de colonialidade, que sobrevivem ao colonialismo operando no campo intersubjetivo, não se restringem aos contextos que envolvem grupos sociais identificados como subalternizados (negros, indígenas, camponeses etc.), mas atravessam diversas relações situadas em contextos educacionais. Assim, o olhar coletivo de professoras e professores desde uma perspectiva das relações de colonialidade pode ser uma forma de deslocar essa discussão para um terreno político.

Perspectivas da Educação Matemática - INMA/UFMS - v. 12, n. 30 - Ano 2019 


\section{Matemática como desobediência político-epistêmica}

Os caminhos de resistência vinculados às políticas de identidade e às metodologias nos colocam, de modo mais ou menos incisivo, a necessidade de revisitar os sentidos ético, estético e/ou político que permeiam a formação de professoras e professores que ensinam matemática. Contudo, ainda que necessária, essa revisitação se constitui como um desafio na medida em que os sentidos atribuídos à formação se aproximam e se tornam indissociáveis dos sentidos que constituem a matemática e, como defendemos, o próprio padrão colonial de poder. Se a matemática atua como metanarrativa da ciência e da sociedade modernas (CLARETO, 2003) e a colonialidade se coloca como o lado mais obscuro da modernidade (MIGNOLO, 2017), podemos sugerir que os sentidos ético, estético e/ou político que constituem a matemática são perpassados por traços do projeto colonial, definindo-a como elemento de extrema importância para conformação da colonialidade. Se nós, professoras e professores que ensinam matemática, somos agentes e efeitos desses traços que se produzem em uma matemática a serviço do projeto colonial; somos também habitantes desse lado obscuro, muitas vezes perpetuadores dessa escuridão. Resta-nos, então, perguntar: quais sentidos estariam nessa pauta oculta da modernidade, imersa em sombras, e como ela define a nós mesmos, professoras e professores que ensinam matemática?

Essa pergunta, que coloca a nós mesmos na centralidade do projeto colonial, não nos incita localizar e analisar práticas individuais pelas quais perpassam traços e efeitos da colonialidade, mas tensionar como um coletivo se produz em torno desses traços e efeitos, entendendo que a voz que nos move profissionalmente, a matemática, atua como dispositivo da colonialidade, produzindo os poderes que gerimos, os saberes que mobilizamos, a natureza que consideramos e a dimensão constitutiva do que somos, do que nunca seremos, do que deixamos de ser e do que podemos vir a ser. Por isso, faz-se relevante compreender como uma espécie de colonização matemática, empreendida particularmente em processos formativos e escolares, produz esse coletivo direcionado a ensinar matemática, reunindo e sedimentando sentidos ético, estético e/ou político que participam desses processos.

Diferentes estudos que contribuíram com este ensaio colocam-se junto a essa inquietação, ainda que com diferentes palavras, frentes teóricas, metodológicas, analíticas e existenciais. Esses estudos evidenciam e tensionam relações que atuam na produção de quem somos, particularmente compreendendo como a matemática participa das regras que a 
colonialidade impõe, na atualidade, ao jogo de produção de nós mesmos. Entendemos que esses tensionamentos nos levam a um repensar dos sentidos ético, estético e/ou político dos processos de formação de professoras e professores por meio da afirmação da matemática não como partícipe desse jogo, mas como uma intrusa, trapaceira e traiçoeira jogadora que, em um movimento de desobediência, irrompe regras estabelecidas e redesenha os sentidos atribuídos a essa formação. Por isso, compreendemos que esses estudos nos convocam a tratar a matemática em uma postura decolonial, como desobediência político-epistêmica.

Nessa direção, Matos e Quintaneiro (2019), por meio de um estudo que interpela a literatura sobre formação de professores, amplificando as vozes de estudantes de um curso de Licenciatura em Matemática, desestabiliza o sentido político da formação de professoras e professores que ensinam matemática ao mostrar

o apagamento da profissão docente pelos próprios licenciandos, ao se referirem à matemática como corpo de conhecimento que define sua futura profissão, suprimindo o termo professor; e o silenciamento do conhecimento matemático para o ensino na formação docente, a partir da naturalização de padrões da colonialidade na licenciatura que apresentam a matemática como corpo único de conhecimento de referência, em uma exposição singular e linear que desconsidera as especificidades dos saberes do professor sobre matemática(s). (MATOS; QUINTANEIRO, 2019, p. 579-580)

Contrapondo-se à subalternação da profissão docente à matemática, seja em seu caráter subjetivo ou epistemológico, reivindica-se nesse estudo um sentido político para a formação de professoras e professores que tenha como elemento a resistência à prevalência da exposição naturalizada da matemática, colocando-a como condição do progresso e como preexistente à vida e à natureza. Assim, abre-se um caminho de resistência em duas frentes: a primeira luta contra a colonialidade do poder, uma hierarquização dos corpos que caracteriza a matemática como uma "capacidade advinda da inspiração isolada de 'gênios' com talento inato" (MATOS; QUINTANEIRO, 2019, p. 571); ao passo que a segunda combate a colonialidade da vida e da natureza, "a dicotomia imposta entre natureza e sociedade e a ruptura que promove entre os mundos biofísicos, humanos e supernaturais (espirituais)" (WALSH, 2012, p. 68), que coloca a matemática a serviço da manutenção de dualismos como natureza/cultura, mente/corpo, abstrato/concreto, entre outros. Trata-se, então, de reivindicar "uma exposição problematizada das matemática(s) que evidencie os múltiplos processos históricos, sociais e culturais de produção do conhecimento matemático, que determinaram a maneira como as matemática(s) estão estabelecidas hoje” (MATOS; QUINTANEIRO, 2019, p. 571). 
Esses dualismos, formas binárias e hierárquicas aos quais professoras e professores de matemática são submetidos, são também discutidos por Gomes, Chisté e Gondim (2018). A autora e os autores evidenciam um sentido da formação de professoras e professores em que essas formas binárias e hierárquicas, muitas vezes estabelecidas em preceitos morais ligados ao que e ao como fazer, determinam uma forma da formação que se alimenta da ideia de que os processos formativos precisam moldar os indivíduos para exercerem papéis pré-determinados, com finalidades universais. Assim, incita-se um sentido ético para a formação de professoras e professores que ensinam matemática determinado por uma moral que os coloca e os obriga a existirem na decisão entre antagonismos; um sentido em que um conjunto de regras e verdades no qual o que e o como assumem valor em si.

Contudo, como caminho de resistência, Gomes, Chisté e Gondim (2018) propõem um sentido ético que supere a moral, em que suas vidas se põem em resistência à forma dominadora, aniquiladora, colonizadora e majoritária; escutando as diferenças e se afirmando junto a essas diferenças. Entendemos que nesse caminho as regras e as verdades não possuem um valor em si, mas só têm valor enquanto conduzidas e exigidas pelo acontecimento - uma fissura, um silêncio, uma passagem. Não se trata, observam a autora e os autores, "de ignorar os conhecimentos adquiridos, ou mesmo de desconsiderá-los, de desprezar as formas, os conteúdos, os procedimentos didáticos, as metodologias, as tendências"; "mas de transformálos em ferramentas que funcionam no engendramento de invenções sem causas" (p. 12), de estabelecer uma formação que se expresse para além das políticas identitárias ou campos de saber delimitados pela colonialidade e que insistem em determinar os modos de (re)existir na docência.

Essa discussão, ligada mais intensamente a uma ética da formação, desdobra-se inevitavelmente em sentidos políticos e estéticos. No âmbito político, essas discussões encontram aquelas apresentadas por Santos e Corrêa (2019), também autores que contribuíram com este ensaio, que mostram como diferentes diretrizes, ideários e imaginários da formação de professoras e professores que ensinam matemática intencionam "listar, elencar e dizer o que o futuro professor de matemática precisa saber em sua formação" (p. 615), de modo que "sempre há uma expectativa de que algo deve ser feito no presente, para que no futuro, os professores de matemática possam lidar de uma 'maneira melhor' com entraves e possibilidades em suas salas de aula" (p. 615-616). Essas diretrizes, ideários e imaginários estão ancorados nos afetos do medo e da esperança, que delimitam uma projeção e imagem de um futuro, em 
uma nítida visão de progresso que supõe um curso linear e único para a história - uma marca do lado mais obscuro da modernidade.

A resistência a esses processos instaura-se em outro afeto, o do desamparo: para além e aquém do medo e da esperança, destituir-se de si mesmo; criar desidentificações e desindividualizações; lutar contra identificações rígidas; criar um espaço no qual somos indiferentes às identidades; e perceber que no si mesmo há muito mais do que o si mesmo, constituindo, assim, espaço para a criação de novas formas de vida (SANTOS; CORRÊA, 2019, p. 634).

Na construção de uma outra política de formação, encontramos na opção decolonial uma voz. A resistência à colonialidade pela formação de professoras e professores não pode se situar simplesmente no tensionamento das identidades culturais, isto é, no que uma professora ou um professor que ensina matemática precisa saber para atuar em um determinado contexto cultural. Assim como Santos e Corrêa (2019), Walsh (2013, p. 55) nos convida a pensar que não é possível superar a colonialidade apenas no âmbito cultural, fazendo-se fundamental atacar as condições ontológicas e existenciais; incidir e intervir em; interromper, transgredir, desencaixar e transformar de maneira que se superem ou se desfaçam as categorias identitárias em suas mais variadas dimensões. Por isso, essa política nos convida a uma estética.

Nesse cenário de controle e de possibilidade de (re)existir na docência, podemos pensar uma estética da formação junto ao estudo de Amaris-Ruidiaz e Silva (2019), que examinam os artifícios neoliberais - e, sugerimos, neocoloniais - que constroem as políticas de formação e de atuação de professoras e professores que ensinam matemática. Trazendo à tona acontecimentos políticos e ações governamentais ligadas à educação que evidenciam o apagamento das pluralidades e multiplicidades, inclusive as culturais, a autora e o autor discutem o engendramento neoliberal para "a constituição de um modo de vida, por meio de uma forma de interioridade, que se toma habitualmente por modelo [...] cuja finalidade é assegurar as condições para dominar, seja por meio de leis ou de ameaças” (p. 586). Essa estética da existência se produz entre dispositivos que tentam controlar e instituir um rosto sedução e captura.

Entretanto, "existe formação de professoras que ensinam (Matemática) fora deste contexto? Ou melhor: existe formação de professoras fora de qualquer contexto? Poder-se-ia dizer de uma formação do (e no) fora?" (GOMES; CHISTÉ; GONDIM, 2019, p. 697) “Como reencontrar a possibilidade de experiência e assim pensar (que fazer) nestes tempos? 
(AMARIS-RUIDIAZ; SILVA, 2019, p. 592) "Até que ponto nossas pesquisas alimentam uma verdade sobre a educação matemática que movimenta dispositivos de controle, materializados, por exemplo, em políticas públicas educacionais?” (AMARIS-RUIDIAZ; SILVA, 2019, p. 590) “[...] seria possível sair deste circuito de afetos em que medo e esperança constituem os corpos dos professores? (SANTOS; CORRÊA, 2019, p. 621)

O estudo de Cammarota, Rotondo e Clareto (2019) ajuda-nos a sustentar tais questões. Tomando a sério diferentes eventos de aulas de matemática, as autoras e o autor perguntam que matemática pode se manter em acontecimento, de modo a insurgir e ressoar sentidos éticos, estéticos e políticos antevistos da formação de professoras e professores. Em contextos reguladores, convidam-nos a resistir interrompendo pela matemática "o bom funcionamento da ordem da distribuição dos corpos em comunidade - coisas, ideias, discursos, matemáticas instituída pela e na lógica da política" (p. 692); propõem-nos entrar no jogo da verdade - não como reprodutores, mas como autores -, "tomar posse, fortalecer-se junto a regras facultativas e, numa prática de liberdade, inventar matemática, inventar mundo: conferir à vida, um estilo" (p. 690); e, finalmente, perguntam-nos, em insurgência: "Que matemática se constitui neste lugar? Que vida se afirma com esta matemática?” (p. 682).

Acreditamos que tomar a sério tem a ver com colocar a matemática como desobediência político-epistêmica, movimentando sentidos da formação de professoras e professores que ensinam matemática. Em um campo político, podemos gerar desestabilizações ao perguntar que matemática contribui para a edificação de um projeto de formação de professoras e professores. Esse projeto, enquanto dispositivo para o exercício de colonialidade, tem um sentido ético, estético e político a ser insistentemente anunciado, embora seja parte desse mesmo projeto velar esse sentido pela afirmação de sua neutralidade. Acontece que recentemente, quando fissurado o argumento da neutralidade e exposta sua incoerência, vimos o desenrolar do caminho oposto: da negação da existência de um sentido ético, estético e político que se configura pela matemática, a neutralidade passou a bandeira para o estabelecimento de uma formação que recuperasse as relações de colonialidade e que justificasse os cenários de regulação e de perda de direitos que hoje vivemos, como se fosse possível uma educação matemática sem partido. Em um campo epistemológico, podemos enunciar sabedorias ausentes, antes subalternizadas, questionando a hegemonia que coloca a matemática à serviço do controle neoliberal e neocolonial das diferentes formas de vida, inclusive das vidas de professoras e professores que ensinam matemática. Por meio de um conjunto de práticas, estratégias e metodologias podemos, 
no campo pedagógico, fortalecer a construção de resistências e insurgências éticas, estéticas e políticas, colocando a matemática em um plano coletivo e a serviço de lutas sociais, ontológicas e epistêmicas: uma desobediência político-epistêmica.

\section{Desmontando caravelas: nós, então, quem somos?}

Que alma tem um povo de um passado sem glória?

O que pode esse povo, privado de história?

Que corpo tem futuro, passado, presente

Se a herança é a dor, chicote, corrente

$\mathrm{Na}$ alma, na mente $[\ldots]$

Se de sangue e estupros somos feitos

Nós então quem somos?

O bandeirante, o missionário

Ou o índio?

O capitão do navio negreiro, o capanga

O capitão do mato, o escravocrata

Ou o quilombola, o capoeira?

O que explora e destrói

Ou o que cultiva a terra?

Ou somos nós a terra

Essa terra, nação diversa

Sem eixo, nem rumo

Dos filhos orfãos que aqui pariu

Pátria amada

De passado em diante tem futuro?

Que futuro tem?

Pra quem?

As autoras e os autores que contribuíram com este ensaio oferecem diversos caminhos de resistência às relações de colonialidade que permeiam os espaços e tempos de formação e de práticas de professoras e professores que ensinam matemática na escola básica.

Tais caminhos de resistência expõem fissuras que atravessam esses espaços e tempos, mas que são sufocadas pelos processos de colonialidade que operam para inibir poderes, invisibilizar saberes, desqualificar seres, corpos e formas de estar no mundo. Essas fissuras se afirmam, então, como lugares de potência - territórios em que nós, atores e sujeitos desses espaços e tempos, habitamos, e partir dos quais reivindicamos as primeiras pessoas das narrativas sobre formação e práticas de professoras e professores que ensinam matemática. Em outras palavras, é habitando nessas fissuras que nos empoderamos para desmontar caravelas, 
para subverter os usos dos dispositivos que servem aos processos da colonialidade. Assim, nos colocamos em posições ativas, atuando para desmontar escola e universidade como instrumentos de um projeto de poder hegemônico. E usamos suas peças desmontadas e ressignificadas - coletivos, metodologias, contextos - para (re)existir, para produzir novos sentidos de educação, de matemática, de práticas docentes e de formação de professoras e professores - sentidos inspirados em sabedorias outras e encarnados em outros corpos.

Tal reinvindicação nos confronta, entretanto, com uma interpelação: Nós, então, quem somos? Que posições éticas, estéticas e políticas assumimos nós, professoras e professores que ensinam matemática, pesquisadoras e pesquisadores em Educação e em Educação Matemática, personagens e autores dessas histórias? Que posições éticas, estéticas e políticas sustentam nossas práticas docentes e de pesquisa em Educação Matemática, e a que projetos políticos servem essas práticas? Que movimentos assumimos não apenas para incorporar em nossas práticas outros sujeitos e outras sabedorias, mas para decolonizar as próprias metodologias e epistemologias em que essas práticas se referenciam?

Nós, então, quem somos? Somos os que reforçam a matemática como metanarrativa central da modernidade euro-eua-cêntrica, e o ensino de matemática como processo de imposição dessa metanarrativa? Ou somos nós os que transgridem, os que subvertem as mesmas peças que constituem o projeto colonial para produzir outra Educação Matemática - uma Educação Matemática como postura e compromisso de desobediência político-epistêmica? Para enfrentar essas interpelações, reivindicamos - no atual momento de regulações e perdas de direitos - as palavras de Paulo Freire, patrono da educação brasileira, como símbolo histórico de caminhos de insurgência e de resistência:

Não existe educação neutra.

Toda neutralidade afirmada é uma opção escondida.

(Paulo Freire, 1972)

\section{Agradecimentos}

Agradecemos profunda e afetuosamente aos participantes das disciplinas Formação de Professores e Matemática Problematizada: Políticas e Resistências, oferecida nos Programas de Pós-Graduação em Ensino de Matemática e em Educação da Universidade Federal do Rio de Janeiro; e Matemática como Desobediência Político-Epistêmica: Leituras Decoloniais, oferecida no Programa de Pós-Graduação em Educação: Conhecimento e Inclusão Social da 
Universidade Federal de Minas Gerais. Nossas reflexões e trocas de saberes nessas disciplinas foram constituintes da construção deste ensaio. Além disso, agradecemos aos colegas do GT19 - Educação Matemática, da ANPEd, pela confiança e pela oportunidade de estarmos juntos construindo este ensaio, o que aproximou nossas agendas de investigação. Particularmente, agradecemos às professoras Andréia Maria Pereira de Oliveira (Deinha) e Cármem Lúcia Brancaglion Passos pela atenção e disposição nesse período.

Artigos aceitos para o Trabalho Encomendado no GT19 na 39 ${ }^{\text {a }}$ Reunião Nacional da ANPEd

AMARIS-RUIDIAZ, P.; SILVA, M. A. Resistindo ao rosto que seduz e captura: um diagnóstico sobre a formação de professores que ensinam matemática, a partir do pensamento de Deleuze e Foucault. Perspectivas da Educação Matemática, v. 12, n. 30, p. 583-597, 2019.

CAMMAROTA, G.; ROTONDO, M. S.; CLARETO, S. Formação docente: exercício ético estético político com matemáticas. Perspectivas da Educação Matemática, v. 12, n. 30, p. 679-694, 2019.

DE PAULA, E. F.; CYRINO, M. C. C. T. Identidade profissional de (futuros) professores que ensinam matemática: uma insubordinação criativa em tempos de resistência. Perspectivas da Educação Matemática, v. 12, n. 30, p. 636-653, 2019.

FORNER. R.; MALHEIROS, A. P. S. Entre contextos opressivos e reguladores: a modelagem como possível resistência à cultura da performatividade. Perspectivas da Educação Matemática, v. 12, n. 30, p. 538-558, 2019.

GOMES, D. O.; CHISTÉ. B. S.; GONDIM, D. M. Contextos e sem-textos: uma formação de professoras (de matemática) para todos e para ninguém. Perspectivas da Educação

Matemática, v. 12, n. 30, p. 695-708, 2019.

LOPES, C. E. A constituição de professores pesquisadores que ensinam matemática e suas identidades profissionais ativistas. Perspectivas da Educação Matemática, v. 12, n. 30, p. 598-611, 2019.

MATOS, D.; QUINTANEIRO, W. Lugares de resistência na formação inicial de professores: por matemática(s) decoloniais. Perspectivas da Educação Matemática, v. 12, n. 30, p. 559$582,2019$.

NACARATO, A. M.; CUSTÓDIO, I. A.; MOREIRA, K. G. Todos juntos somos fortes: compartilhando narrativas de práticas de professoras que ensinamaprendem nos anos iniciais. Perspectivas da Educação Matemática, v. 12, n. 30, p. 519-537, 2019. 
SANTOS, J. R. V.; CORRÊA, J. F. Formação de professores de matemática e circuito de afetos: o desamparo como possibilidade para formações sem intenção de formar.

Perspectivas da Educação Matemática, v. 12, n. 30, p. 612-635, 2019.

TOMAZ, V. S. A formação intercultural para educadores indígenas: possibilidades e formas de resistência. Perspectivas da Educação Matemática, v. 12, n. 30, p. 654-678, 2019.

ZAIDAN, S. Transdisciplinaridade, ensino e formação de professores de matemática. Perspectivas da Educação Matemática, v. 12, n. 30, p. 502-518, 2019.

\section{(Demais) Referências}

CASTRO-GÓMEZ, S. Decolonizar la universidad. La hybris del punto cero y el diálogo de saberes. In: CASTRO-GÓMEZ, S.; GROSFOGEL, R. (Eds.). El giro decolonial: reflexiones para una diversidade epistémica más allá del capitalismo global. Bogotá: Siglo del Hombre Editores; Universidad Central, Instituto de Estudios Sociales Contemporáneos y Pontificia Universidad Javeriana, Instituto Pensar, 2007. p. 79-92.

CLARETO, S. M. Terceiras Margens: um estudo etnomatemático de espacialidades em Laranjal do Jari (Amapá). Tese de Doutorado em Educação Matemática, Universidade Estadual Paulista "Júlio de Mesquita Filho", 2003.

COCHRAN-SMITH, M.; LYTLE, S. Relationships of knowledge and practice: teacher learning in communities. Review of Research in Education, London, n. 24, p. 249-305, 1999.

DUSSEL, E. 1492: El encubrimiento del Otro. Hacia el origen del mito de la Modernidad. Madrid: Nueva Utopía, 1992.

FANON, F. Pele Negra, Máscaras Brancas. Salvador: EDUFBA, 2008.

FERNANDES, F. S.; ARAÚJO, P. H. S.; COSENZA, L. H. C. A. Didática Especial e História da Educação Matemática: Contribuições de um estudo sobre a formação de professores de matemática na Faculdade de Filosofia de Minas Gerais (Belo Horizonte, 19411954). Acta Scientiae, Canoas (RS), v. 21, n. especial, p. 123-136, maio/jun. 2019.

FIORENTINI, D. Learning and professional development of the mathematics teacher in research communities. Journal of Education, v. 1, n. 3, p. 152-181, 2013.

GIRALDO, V. Formação de professores de matemática: para uma abordagem problematizada. Ciência \& Cultura, v. 70, p. 37-42, 2018.

GIRALDO, V.; QUINTANEIRO, W.; MOUSTAPHA, B.; MATOS, D.; MELO, L.; MENEZES, F.; DIAS, U.; COSTA NETO, C.; RANGEL, R.; CAVALCANTE, A.; ANDRADE, F.; MANO, V.; CAETANO, M. Laboratório de práticas matemáticas para o ensino. In: OLIVEIRA, A. M. O; ORTIGÃO, M. I. R. (Eds.). Abordagens Teóricas e Metodológicas na Pesquisa em Educação Matemática. Brasília: SBEM, 2018. p. 186-209. 
GOMES, M. L. M. Os 80 anos do primeiro curso de Matemática brasileiro: sentidos possíveis de uma comemoração acerca da formação de professores no Brasil. BOLEMA, Rio Claro (SP), v. 30, n. 55, p. 424-438, ago. 2016.

LANDER, E. Pensamiento crítico latinoamericano: la impugnación del eurocentrismo. Revista de Sociologia, n. 15, p. 13-25, 2001.

MALDONADO-TORRES, N. Sobre la colonialidad del ser: contribuciones al desarrollo de un concepto. In: CASTRO-GÓMEZ, S.; GROSFOGEL, R. (Eds.). El giro decolonial: reflexiones para una diversidade epistémica más allá del capitalismo global. Bogotá: Siglo del Hombre Editores; Universidad Central, Instituto de Estudios Sociales Contemporáneos y Pontificia Universidad Javeriana, Instituto Pensar, 2007, p. 127-168.

MATOS, D. Experiências com Matemática(s) na Escola e na Formação Inicial de Professores: Desvelando Tensões em Relações de Colonialidade. Tese de Doutorado em Ensino e História da Matemática e da Física, Universidade Federal do Rio de Janeiro, 2019.

MIGNOLO, W. D. Colonialidade: o lado mais obscuro da modernidade. Revista Brasileira de Ciências Sociais, v. 32, n. 94, p. 1-18, jun. 2017.

MOREIRA, P. C.; FERREIRA, A. C. O Lugar da Matemática na Licenciatura em Matemática. BOLEMA, Rio Claro (SP), v. 27, n. 47, p. 981-1005, dez. 2013.

QUIJANO, A. Colonialidad del poder y clasificación social. Journal of World Systems Research, v. VI, n. 2, p. 342-386. 2000.

RAMALHO, F.; PORTA, L. Las historias en la educación y los otros mundo posibles. Revista Interinstitucional Artes de Educar, Rio de Janeiro (RJ), v. 3, n. 3, p. 238-271, jan. 2018.

SUCUPIRA, N. Da Faculdade de Filosofia à Faculdade de Educação. Revista Brasileira de Estudos Pedagógicos, v. 51, n. 114, p. 261-276. 1969.

TARDIF, M.; LESSARD, C.; LAHAYE, L. Os professores face ao saber: esboço de uma problemática do saber docente. Teoria e Educação, v. 4, p. 215-233, 1991.

SANTOMÉ, J. T. Políticas educativas y construcción de personalidades neoliberales y neocolonialistas. Madri: Morata, 2017.

WALSH, C. Interculturalidad, plurinacionalidad y decolonialidad: las insurgencias políticoepistémicas de refundar el Estado. Tabula Rasa, n. 9, p. 131-152. 2008.

WALSH, C. Interculturalidad y (de)colonialidad: ensayos de Abya-Yala. Quito: Abya-Yala, Instituto Científico de Culturas Indígenas, 2012. 
WALSH, C. Lo pedagógico y ló decolonial: entretejiendo caminos. In: WALSH, C. (Org.). Pedagogías decoloniales: prácticas insurgentes de resistir, (re)existir y (re)vivir. Quito: Abya Yala, p. 23-68, 2013.

WALSH, C. ¿Interculturalidad y (de)colonialidad? Gritos, grietas y siembras desde Abya Yala. In: DINIZ, A. G.; PEREIRA, D. A. (Coords.). Poéticas y políticas da linguagem em vías de descolonização. Foz Iguaçu: Universidad de Integración Latinoamericana, 2017, p. 19-53.

Submetido em Março de 2019

Aprovado em Maio de 2019 